\title{
Altitudinal Variation of the Floristic Communities in Monaragala, an Isolated Hill in Eastern Sri Lanka
}

\author{
Fernando R.H.S.S. ${ }^{1}$, Gunatilleke I.A.U.N. ${ }^{1}$, Gunatilleke C.V.S. ${ }^{1}$, \\ Bambaradeniya C.N.B. ${ }^{2}$ and Wijesundara D.S.A. ${ }^{3}$ \\ ${ }^{I}$ Department of Botany and Postgraduate Institute of Science, University of Peradeniya, \\ Peradeniya, Sri Lanka \\ ${ }^{2}$ Tidewaterinc., New Orleans, Los Angeles, USA \\ ${ }^{3}$ Department of National Botanic Gardens, Peradeniya, Sri Lanka \\ *suranjanfernando@gmail.com
}

\begin{abstract}
Compared to wet zonehills of Sri Lanka, the floristic communities of hills in drier regions of its first peniplane has been poorly studied. This study investigatedthe floristic communities along the altitudinal gradient in Monaragala, an isolated hill in the intermediate zone of the island, by sampling trees and lianas $>10 \mathrm{~cm}$ g bh, in 99 randomly located $10 \mathrm{~m}$ x10 m plots in four transects laid on different aspects of the hill.

In the $9,900 \mathrm{~m}^{2}$ sampled in the study, 1,322 individuals were enumerated. They represented 44 families, 103 genera and 149 species, among which 45 were endemic to Sri Lanka. From multivariate analysis of the plot data, one grassland / savanna and five forest communities separated in relation to their variations in elevation and topography, disturbance level and physiognomy of the vegetation. These communities were: two disturbed tall forests, one restricted to low-elevation 210-780 $\mathrm{m}$ (LDT) and the other widespread at $540-620 \mathrm{~m} / 920-$ $950 \mathrm{~m}$ (WDT); three undisturbed tall forests, one at mid-elevation 600-880 m (MUT) and the other two on ridge slopes of Sirigala (RUT) and Maragala (IUT) at $880-1100 \mathrm{~m}$, and the last a high-elevation disturbed grassland/savanna at 720 - 870 m (HDG).
\end{abstract}

The five leading families in each of the six communities collectively represented 31 of the 44 families identified in the study, reflecting familial diversity among the communities. The dominant families were Sterculiaceae and Rutaceae in the lower elevation, while Lauraceae, Dipterocarpaceae, Myrtaceae, Bombacaceae and Apocynaceae were in mid - and upper elevations. Euphorbiaceae was common to all altitudinal ranges.

Most species were restricted to a particular elevation range. At the lower range, Diospyros ebenum, Pterospermum suberifolium, Miliusa indica, Acronychia pedunculata, Alphonsea sclerocarpa, Chlorocarpa pentaschista and Drypetes sepiaria. The mid- and higher range harboured endemic species and those common to wet zone rainforests, eg. Actinodaphne elegans, A. ambigua, Cullenia ceylanica, Cryptocarya wightiana, Hunteria zeylanica, Calophyllum tomentosum, Dipterocarpus zeylanicus.

This study emphasizes that isolated hill forests located outside the wet zone, like Moneragala, harbour diverse and unique floral assemblages which need urgent conservation in a rapidly developing era.

Keywords: Isolated hill forests, Intermediate zone, Moneragala, Sri Lanka, Altitudinal gradient, Floristic communities, Biodiversity conservation 